\title{
Routine screening of harmful microorganisms in beach sands: Implications to public health
}

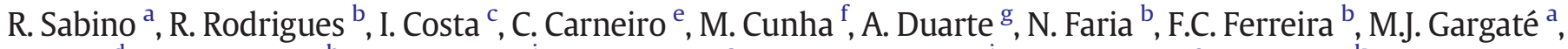 \\ C. Júlio $^{\text {d, }}$ M.L. Martins ${ }^{\text {h }}$, M.B. Nevers ${ }^{i}$, M. Oleastro ${ }^{c}$, H. Solo-Gabriele ${ }^{\mathrm{j}}$, C. Veríssimo $^{\mathrm{a}}$, C. Viegas $^{\mathrm{k}}$, \\ R.L. Whitman ${ }^{\mathrm{i}}$, J. Brandão ${ }^{\mathrm{a}, *}$
}

${ }^{a}$ Reference Unit for Systemic Infections and Zoonosis, Department of Infectious Diseases, National Institute of Health Dr. Ricardo Jorge, Portugal

${ }^{\mathrm{b}}$ Microbiology Laboratory, Department of Environmental Health, National Institute of Health Dr. Ricardo Jorge, Portugal

c Laboratory of Molecular Biology, Department of Infectious Diseases, National Institute of Health Dr. Ricardo Jorge, Av. Padre Cruz, 1649-016 Lisbon, Portugal

${ }^{d}$ Reference Unit for Gastro-intestinal Infections, Department of Infectious Diseases, National Institute of Health Dr. Ricardo Jorge, Portugal

e REQUIMTE/Centro de Química Fina e Biotecnologia, Departamento de Química, Faculdade de Ciências e Tecnologia, Universidade Nova de Lisboa, Portugal

${ }^{\mathrm{f}}$ Portuguese Environment Agency, Environment Reference Laboratory, Portugal

${ }^{g}$ Faculty of Pharmacy, iMed.UL-Research Institute for Medicines and Pharmaceutical Sciences, University of Lisboa, Portugal

${ }^{\text {h }}$ Unit of Medical Microbiology, Instituto de Higiene e Medicina Tropical-Centro de Recursos Microbiológicos (CREM), Universidade Nova de Lisboa (UNL), Portugal

${ }^{\mathrm{i}}$ United States Geological Survey, Great Lakes Science Center, Porter, IN, USA

${ }^{j}$ Department of Civil, Architectural, and Environmental Engineering, University of Miami, Coral Gables, FL, USA

${ }^{\mathrm{k}}$ Lisbon School of Health Technology, Polytechnic Institute of Lisboa, Portugal

\section{A R T I C L E I N F O}

\section{Article history:}

Received 12 August 2013

Received in revised form 29 October 2013

Accepted 18 November 2013

Available online $\mathrm{xxxx}$

\section{Keywords:}

Beach sand

Public health

Microorganisms

\begin{abstract}
A B S T R A C T
Beaches worldwide provide recreational opportunities to hundreds of millions of people and serve as important components of coastal economies. Beach water is often monitored for microbiological quality to detect the presence of indicators of human sewage contamination so as to prevent public health outbreaks associated with water contact. However, growing evidence suggests that beach sand can harbor microbes harmful to human health, often in concentrations greater than the beach water. Currently, there are no standards for monitoring, sampling, analyzing, or managing beach sand quality. In addition to indicator microbes, growing evidence has identified pathogenic bacteria, viruses, and fungi in a variety of beach sands worldwide. The public health threat associated with these populations through direct and indirect contact is unknown because so little research has been conducted relating to health outcomes associated with sand quality. In this manuscript, we present the consensus findings of a workshop of experts convened in Lisbon, Portugal to discuss the current state of knowledge on beach sand microbiological quality and to develop suggestions for standardizing the evaluation of sand at coastal beaches. The expert group at the "Microareias 2012" workshop recommends that 1 ) beach sand should be screened for a variety of pathogens harmful to human health, and sand monitoring should then be initiated alongside regular water monitoring; 2) sampling and analysis protocols should be standardized to allow proper comparisons among beach locations; and 3) further studies are needed to estimate human health risk with exposure to contaminated beach sand. Much of the manuscript is focused on research specific to Portugal, but similar results have been found elsewhere, and the findings have worldwide implications.
\end{abstract}

(C) 2013 Elsevier B.V. All rights reserved.

\section{Introduction}

The beaches and shorelines are some of the more highly valued areas for recreation around the world, responsible, in many areas for significant tourism industry revenue (UNWTO, 2010). Portugal is no exception and its climate generates a relevant role in Western Europe's shore lines. Over the past decade, there has been a significant increase in the number of beachgoers visiting these areas, resulting in simultaneous

\footnotetext{
* Corresponding author.

E-mail address: joao.brandao@insa.min-saude.pt (J. Brandão).
}

build-up of housing (including motels and hotels) and restaurants, along the entire coast. Maintaining the integrity of these areas for public health is of utmost importance for the economic viability of coastal communities: a disease outbreak associated with beaches will have severe negative economic impacts on the surrounding communities. For example, during the production of this paper, the Lisbon area went through such a scenario (General Directorate of Health - July, 15th, 2013 www.dgs.pt).

Water quality is currently monitored at recreational beaches to assess the risk of water-borne illnesses to beachgoers. The abundances of the bacteria Escherichia coli (freshwater) or enterococci (marine) 
are used to assess whether water conditions are suitable for swimming within the European Union state members (Directive, 2006/7/EC). Allowable levels after the local publishing of the latest revision of this directive in May 2012 (Law-decree 113/2012) include single sample maximums 1200 and $1800 \mathrm{CFU} / 100 \mathrm{~mL}$ for E. coli and 350 and $600 \mathrm{CFU} / 100 \mathrm{~mL}$ for enterococci, for coastal and transient waters and for inland waters, respectively. Although most of the local European regulations focus on reducing the number of water indicators through improved hygiene on surrounding areas, as imposed by the current European Directive, national surveys conducted by the authors on sand have shown that regulated beaches do not necessarily comply with the maximum locally determined mean levels, especially for fungi (including blue flag awarded beaches; Brandão et al., 2002 and Sabino et al., 2011 (10 CFU/g for enterococci, $25 \mathrm{CFU} / \mathrm{g}$ for E. coli, $15 \mathrm{CFU} / \mathrm{g}$ for yeasts, $17 \mathrm{CFU} / \mathrm{g}$ for potential pathogenic fungi, $8 \mathrm{CFU} / \mathrm{g}$ for dermatophytes)). In the USA, these same bacteria are used for monitoring recreational water quality (US Environmental Protection Agency, 2012) with single sample maximums of $235 \mathrm{CFU} / 100 \mathrm{~mL}$ for $E$. coli and $104 \mathrm{CFU} / 100 \mathrm{~mL}$ for enterococci. These bacteria were selected due to their direct association with infections and are usually referred to as fecal indicator bacteria (FIB). Epidemiological studies have shown that the presence of these FIB at densities higher than those recommended by the Environmental Protection Agency (US) are linked to swimmer's gastro-intestinal (Haile et al., 1999; Wade et al., 2003) and skin illnesses (Sinigalliano et al., 2010). Although existing legislation focuses on measuring bacteria in water, sand is not included within the regulatory framework (Pereira et al., 2013). Transmission of microbes from the sand to the water can occur through tidal washing in the intertidal zone. Sand also represents a direct source of illness through skin contact and through ingestion via hand-to-mouth activity, especially among beachgoers who play in the sand (Whitman et al., 2009).

There is little consensus on what indicator microorganism(s) to use in monitoring the health risks associated with beach sand. This lack of consensus is mainly a result of the paucity of studies involving the monitoring of sands. Epidemiological studies have just begun to evaluate the risks of illness associated with beach sand contact, with studies suggesting a link between sand quality and human health impacts (Bonilla et al., 2007; Stone et al., 2008; Wade et al., 2008; Heany et al., 2009; Whitman et al., 2009; Heaney et al., 2012).

The aim of the work presented here is to provide new insights on the issue of health risks associated with beach sands. Much of what we present is collated from a recent workshop convened on October 26, 2012, at the National Institute of Health Dr. Ricardo Jorge, Lisboa, Portugal, under the name "Microareias 2012". This workshop was organized to discuss and summarize current knowledge and data on microbiological quality of beaches. Specifically, multidisciplinary working groups were formed to address the following objectives: (1) evaluate microbiological agents in sands of bathing areas that can cause disease (coastal and inland), (2) assess agent sample collection and methods of detection and identification, and (3) provide recommendations to help address the human health risks associated with pathogen presence in beach sands. What follows, here, is a compilation of the state-of-the knowledge for the three workshop objectives.

\section{Microbiological agents found in sands of bathing areas}

There is evidence (Stewart et al., 2008) that beach sand can harbor fecal indicator organisms (FIO), as well as pathogenic bacteria (Pseudomonas spp., Salmonella spp., Shigella spp., Campylobacter jejuni, Staphylococcus aureus, Vibrio parahaemolyticus and, Vibrio harveyi), fungi (Candida spp. and, dermatophytic fungi), parasitic nematodes and viruses (adenovirus, norovirus, enterovirus). Some of these microbes are transmitted through fecal oral routes (Pseudomonas, Salmonella, Shigella, Campylobacter and viruses) whereas others are mainly transmitted through direct contact with skin (Staphylococcus, Vibrio, Candida, dermatophytes and other keratinophylic fungi as well as nematodes) and through inhalation (sporulating opportunistic and/or allergenic fungi). Pinto et al. (2012) found elevated levels of fecal indicators and parasites in the sand of beaches from São Paulo, Brazil. Abdelzaher et al. (2010) found that enterococci in sand beaches of a south Florida, USA beach correlated with supplemental FIB (fecal coliforms, E. coli, and Clostridium perfringens) in both water and sand samples. Pathogens were detected predominantly during the same sampling event that resulted in the highest indicator microbe levels. Collectively these results suggest a potential relationship between pathogens and FIB in sand. The subsequent sections begin by describing the presence of FIB in beach sands and then subsequently describe pathogenic fungi, parasites, and viruses that have been found in beach sands and that could pose potential risks to beachgoers.

\subsection{Bacteria}

Numerous studies have shown that beach sand may serve as a reservoir for pathogens harmful to human health and indicator microbes that can be released into surrounding waters through tidal action or run-off (Alm et al., 2003; Whitman and Nevers, 2003; Boehm and Weisberg, 2005; Beversdorf et al., 2007; Colford et al., 2007; Fleisher et al., 2010; Ge et al., 2010; Sinigalliano et al., 2010; Abdelzaher et al., 2010). Several authors have reported that both indicator bacteria and potential pathogens occur in beach sands of both freshwater and marine environments (Sanchez et al., 1986; Ghinsberg et al., 1994, 1995; Obiri-Danso and Jones, 2000; Desmarais et al., 2002; Sato et al., 2005; Vantarakis et al., 2005; Beversdorf et al., 2007; Bonilla et al., 2007; Vogel et al., 2007; Hartz et al., 2008; Abdelzaher et al., 2010). In fact, bacterial cell numbers can be substantially higher in the sand than in nearby waters; for example in the Great Lakes region of the US, E. coli in sand can be found at levels of 10 to 100 times higher than adjacent waters, generally ranging from $10^{3}$ to $10^{4} \mathrm{CFU} / \mathrm{g}$ at an enclosed beach to $10^{1.5}$ to $10^{2.5} \mathrm{CFU} / \mathrm{g}$ at open beaches (Burton et al., 1987; Doyle et al., 1992; Irvine and Pettibone, 1993; Oshiro and Fujioka, 1995; Whitman and Nevers, 2003; Yamahara et al., 2007). This phenomenon might be of even greater concern in high-latitude regions where bathers spend more time on the beach itself than in the water (WHO, 2003).

Sands within and near intertidal zones can contain nutrients that may promote survival and growth of such indicator bacteria and pathogens (Papadakis et al., 1997; Shah et al., 2011). The origins of these microorganisms in sand are often unclear, but they are likely from both exogenous (e.g., sewage or run-off) and/or indigenous sources (e.g., regrowth within the sediments) (Ferguson et al., 2005) and from humans and animals present on the beach (Wright et al., 2009). The presence, persistence, and accumulation of FIB in sediments show that beach sands are likely reservoirs for these microbes and thus can have an impact on water quality (Byappanahalli et al., 2003; Boehm and Weisberg, 2005; Beversdorf et al., 2007; Yamahara et al., 2007; Hartz et al., 2008; Halliday and Gast, 2011).

Enterococci have been detected in beach sediments where there may not be a clear, nearby source of sewage (Whitman and Nevers, 2003; Shibata et al., 2004; Abdelzaher et al., 2010; Badgley et al., 2010; Wright et al., 2011); sources of enterococci from sewage are relatively easier to identify and control. Harmful bacteria resident in beach sediments can be resuspended in surrounding waters as a result of agitation from recreational activity or storms during the summer season (Abdallah et al., 2005). Release of enterococci from beach sands following a significant rainstorm has been reported (Phillips et al., 2011a). Moreover, such rain events resulted in a number of preemptive beach closures due to FIB, representing $21 \%$ of the closures at US beaches in 2009 (Dorfman and Rosselot, 2010).

Enterococci levels are directly correlated with levels of human pathogens in beach sand (Shah et al., 2011). Due to this risk to human health, it is important to assess the contribution of microorganisms harbored in beach sediment to the overall quality of the beach and associated recreational water (Phillips et al., 2011b). High enterococci levels in beach water represent an increased health risk for beachgoers who enter the 
water (Fleisher et al., 2010; Sinigalliano et al., 2010). In fact, a pilot epidemiological study conducted by Bonilla et al. (2007) demonstrated that gastrointestinal illness in beach users was associated with exposure to water and intertidal sand, whereas contact with the sand in upper beach areas did not result in such illnesses (Pinto et al., 2012). However, the capacity of bacterial pathogens in beach sand to infect beach users remains unclear. The cause-effect or a possible dose-response relationship linking the microbial quality of beach sand with skin, eye, ear and mucous membrane infections is also unknown. Bacteria such as $S$. aureus and Pseudomonas aeruginosa, responsible for these infections may be appropriate non-enteric indicator organisms. S. aureus cross-infection was found among bathers in recreational waters, as well as a correlation between skin infections and levels of $P$. aeruginosa in seawater (Field and Samadpour, 2007). S. aureus possesses a wide tolerance for environmental stresses such as high salinity and variations in osmotic pressure. High levels of S. aureus and P. aeruginosa, previously reported at three South Florida beaches (Esiobu et al., 2004), may be explained by the ability of these organisms to replicate in sand over a range of conditions, and the sand may also offer an environment favorable to pathogen growth through biofilm development (Hartz et al., 2008). Biofilms provide protection against extreme changes in moisture, salinity, and other environmental variables as well as provide some protection against predators, as reviewed in Fanning and Mitchell (2012).

The consensus among meeting participants was to not expand the bacteriological parameters currently in use, as they match the ones used on water quality assessment (E. coli and enterococci). However, it is recognized that other bacteriological agents have been recommended by other groups including $C$. perfringens as utilized by the State of Hawai'i, USA (US EPA, 2000) and Bacteroidales as evaluated through many research studies (Layton et al., 2013). Moreover, in the case of suspected bacterial outbreaks caused by other bacterial species, health authorities or beach management should request the isolation and identification of the causative agents.

\subsection{Fungi}

A number of studies have detected certain species of fungi in beach sand. Some of the fungi remained viable in sand under laboratory conditions for up to six months (Carillo-Muñoz et al., 1990). In seawater, fungi remained viable for a year (Anderson, 1979). It was further demonstrated that some fungi isolated from seawater could even survive under conditions of high salinity and temperatures, exceeding those of the natural seawater habitat. This finding confirmed that seawater could serve as a niche for potentially pathogenic fungi in both natural conditions as well as within extreme environments.

An effective method for measuring fungi proposed by Sabino et al. (2011) divides fungi into three practical groups: yeasts, potentially pathogenic and allergenic fungi, and dermatophytes. These fungal groups include all yeasts (except the black yeasts), the filamentous fungi of species of Aspergillus, Fusarium, Scopulariopsis, Scedosporium, Chrysosporium, Scytalidium, and, finally, all of the dermatophytes (Trichophyton, Microsporum and Epidermophyton) of clinical relevance. Many of the fungi in these groups are ubiquitous in nature and are not necessarily pathogenic. However, within the past few years a number of clinical cases involving infections by these fungi have been detected (mainly respiratory, skin and nail infections) (Nucci and Anaissie, 2007; Cortez et al., 2008; Knutsen and Slavin, 2011; Morrissey, 2013). Most of these cases have involved patients who are immunocompromised, and thus, relatively more vulnerable to infection by opportunistic pathogens. But, some cases have involved patients who are immunocompetent (Chanqueo et al., 2009). Indeed, species of the opportunistic fungi Scedosporium have become increasingly recognized as an emerging pathogen among the ever-increasing population of immunocompromised individuals. This is borne out of the growing number of reports and publications over the past few years of infections by this genus (Cortez et al., 2008).
Fungi associated with endemic infections (e.g., cocciodiomycosis and histoplasmosis) and any other fungi found in sand samples at $>500 \mathrm{CFU} / \mathrm{g}$ of sand should be reported, according to Sabino et al. (2011). Detection of any of the following fungi was considered to be of special concern among the participants of the workshop: Cryptococcus gattii, Cryptococcus neoformans, Histoplasma capsulatum, and Cladophialophora bantiana. C. gattii is classically considered to be geographically restricted to countries with tropical and subtropical climates. Nevertheless, several authors reported environmental $C$. gattii in soil and vegetable material (live and decaying plants and trees) in Europe (Chowdhary et al., 2012). C. neoformans var. neoformans is responsible for most cases of cryptococcosis in immunocompromised patients whereas $C$. gattii has been associated with infections in patients having a normal immunologic status. H. capsulatum var. capsulatum is the etiologic agent of non-African histoplasmosis. The spectrum of its pathologies varies from benign pulmonary infection to severe disseminated infection in immunocompromised individuals. H. capsulatum is considered an endemic fungus of the Tennessee, Ohio, and Mississippi river basins occurring especially in soils contaminated with droppings of birds and bats. Moreover, an increasing number of autochthonous cases of histoplasmosis have been described in Europe (Ashbee et al., 2008).

Also of concern, especially recently, is C. bantiana - a phaeoid fungus with worldwide distribution. It is the most common microorganism involving non-traumatic infections of the central nervous system. Infections by this fungus have even been found in immunocompetent, young individuals who have no underlying risk factor for fungal infection (Ganavalli and Kulkarni, 2001). There are only a few reports of its isolation from nature. The precise ecological niche of this fungus is unknown, but it is believed to occur in the soil, as suggested by the association of infection by C. bantiana with farming (Ganavalli and Kulkarni, 2001). The workshop participants believe the resemblances between many farming terrains and freshwater catchment environments in terms of soil quality, moisture content, and organic content of composition raise some concern on this specific fungus given the described above.

\subsection{Parasites}

Water continues to be a major reservoir and conduit for transmission of many parasites. Waterborne parasitic organisms of human concern, associated with beaches and sand, are generally disseminated into the environment in the feces or urine of infected animals or humans. This is especially the case with the protozoan parasites, such as Giardia duodenalis, Cryptosporidium sp., and Toxoplasma gondii, and the helminth Toxocara sp. (Slifko et al., 2000). Waterborne transmission plays a major role in the transmission of these parasites to the population, at large. Several outbreaks of giardiasis, cryptosporidiosis, toxoplasmosis, and toxocarosis, to one degree or another, are attributed to water and food transmission via (oo)cysts or ova of these parasites (Yilmaz and Hopkins, 1972; Benenson et al., 1982; Mac Kenzie et al., 1994; Bowie et al., 1997; Cotte et al., 1999; Slifko et al., 2000). In such cases, human infection can occur either by direct consumption or by the use of contaminated water in food processing or preparation. The presence of these parasites in irrigation waters can lead to contamination of the food supply. However, they can also be found in fresh and marine waters of recreational areas.

The presence of fecal pathogens from terrestrial animals in coastal waters and filter-feeding shellfish has been previously documented (Shapiro et al., 2010). These have lead to reports of infections and deaths in aquatic wildlife and humans who became exposed to these parasites either through recreational activities or consumption of seafood.

Giardia and Cryptosporidium are the most common enteric protozoa associated with human gastroenteritis, worldwide, and are among the top ten major human parasites (Thompson et al., 2000; Smith et al. 2007; Sunderland et al., 2007). G. duodenalis causes an estimated $2.8 \times 10^{8}$ cases per year (Lane and Lloyd, 2002). In Portugal the 
prevalence of giardiasis in asymptomatic children residing in the Lisbon region was 6.9\% (Júlio et al., 2012a). The annual human incidence for infection by Cryptosporidium in the year 2000 was estimated at 1.17 per 100,000 persons (Groseclose et al., 2002). Matos et al. (1998) found a prevalence of $8 \%$ of HIV patients that had diarrhea were infected with Cryptosporidium.

T. gondii is a protozoan pathogen that infects vertebrates, including humans; oocysts of this protozoan are excreted into the environment mainly in the feces of felids (Dubey, 1998). These oocysts can survive in terrestrial and aquatic environments. The prevalence of toxoplasmosis in humans varies between 35\% in southern and 70\% in northern Portugal (Lopes et al., 2012). In a recent study, there were 11 cases of human congenital toxoplasmosis (CT) per 10,000 births, which means an estimate of 124 CT cases per year were found (Ângelo, 2003). In Lisboa and the surrounding area, toxoplasmosis seroprevalence was $71 \%$ for a sample of 145 cats. Another study (Waap et al., 2012) determined that there was an overall prevalence of $44.2 \%$ of $T$. gondii in cats, which was in line with the $30-40 \%$ estimated seroprevalence of T. gondii in cats worldwide (Elmore et al., 2010).

Toxocarosis is a zoonotic disease caused by larvae of the helminthic worm, Toxocara. This ascarid roundworm has a worldwide distribution. Species of Toxocara having human and animal health significance are essentially represented by Toxocara canis and Toxocara cati, parasites of canids and felids, respectively. According to recent data, the prevalence of $T$. canis or $T$. cati is variable but remains high, up to $64.7 \%$ for T. canis and $55.2 \%$ for T. cati, respectively (Chen et al., 2012).

Based on a two-year large-scale survey assessing the occurrence of Giardia and Cryptosporidium at 19 river beaches in the larger Portuguese river basins, these parasites were widespread in river basins $(85 \%$ and $82 \%$ respectively - Júlio et al., 2012b). Abdelzaher et al. (2010) found Giardia cysts in water and Cryptosporidium oocysts in sand when the highest levels of indicator microbes were detected. In a study carried out in Champagne-Ardenne Region, France, T. gondii DNA was detected in several environmental samples (underground water, raw surface water) including public drinking water (Aubert and Villena, 2009). No records were found of detecting $T$. gondii in beach sand. Moreover, these robust parasitic stages are capable of persisting for an extended period of time in the environment and are highly resistant to treatment by various chemicals, or other disinfecting methods, commonly used by the municipal water supply industry (Korich et al., 1990; Dumètre et al., 2008). In a study of two sand beaches in Marseilles, France, T. canis was the most common parasite, detected regularly in $150 \mathrm{~g}$ of sand (Conseil Supérieur d'Hygiène Publique de France, 1990). However, in a study carried out on "dog beaches" in Perth, Australia, a total of 266 samples showed no trace of $T$. canis eggs or other eggs/larvae of parasitic nematodes (Dunsmore et al., 1984). It was emphasized in this study that the major risk to humans was from an environment in which puppies, not older dogs, were found. According to the literature, it is assumed that common sources of indicator pathogens at beach sites include dogs and birds (Wright et al., 2009).

The discussion at the "Microareias 2012" meeting had the agreement among all of the participants that Giardia sp., Cryptosporidium sp., $T$. gondii, and Toxocara sp. be analyzed in microbiological sand quality.

\subsection{Viruses}

Not many reports can be found on viruses having been investigated in recreational sand areas but their presence could be potentially hazardous to human health as reported by WHO (2003). Meeting participants, therefore, recommend that viral detection technology is worth pursuing for use in assessing recreational beaches. The health risks of viruses are summarized below.

Enteroviruses (Coxsackie viruses, echoviruses and hepatitis A), adenoviruses, and enteric viruses (noroviruses, astroviruses, adenoviruses 40 and 41) are the viruses most frequently implicated in outbreaks of recreational water-borne diseases. Many epidemiological studies show there is an alarming increase in the incidence of viral infections in immunocompromised individuals or people participating in recreational activities in both marine water and freshwater, including gastrointestinal, respiratory, ear, eye, skin and other more serious infections with high morbidity and mortality, such as meningitis, encephalitis and paralysis (Sinclair et al., 2009; Okoh et al., 2010).

Studies in Europe and the USA suggest that most infections contracted as a result of swimming, canoeing, or other recreational use of sewage-polluted water may be viral in nature (Wyn-Jones et al., 2010). Viruses may persist in the environment as they are known to be more resistant to degradation than bacteria (Vasl et al., 1981) and are transmissible by a number of routes. Enteric viruses, for example, are diverse, and can be transmitted from person to person or through contact with contaminated food or water. Their spread is usually associated with insufficient hygiene or sanitation (Wyn-Jones and Sellwood, 2001).

Human noroviruses are the most common agent of acute viral gastroenteritis in people of all age groups. Moreover, the short duration of protective immunity from prior norovirus infections, together with the large number of immunologically distinct strains, explains the abundance of norovirus outbreaks in the populations of both developed and developing countries (Wyn-Jones and Sellwood, 2001; Okoh et al., 2010). Additionally, noroviruses have been reported to be the principal cause of waterborne illnesses, estimated to cause more than $80 \%$ of all nonbacterial waterborne outbreaks (Sinclair et al., 2009; Gibson and Schwab, 2011).

Enteric adenovirus is the second most prevalent agent associated with viral illnesses (Sinclair et al., 2009). They are highly prevalent and very stable, and more resilient to body exogenous conditions than enterovirus, due to their structure. Human adenovirus has therefore been proposed as a suitable index to indicate viral contamination by humans. In addition, both norovirus and adenovirus possess properties that favor their efficient spread via the environment: their abundant excretion into the environment by those infected, their resistance to heat and disinfection (Okoh et al., 2010), and their exceptional survival time in both dry and moist environments (Maunula et al., 2004).

Since the late 1970s, virus measurements have been considered for water quality monitoring. Bathing water quality in the European Union (EU) has been regulated since 1976 under the Bathing Water Directive (BWD) (76/160/EEC). Initially, this Directive included the enterovirus parameter (CEU, 2006. Directive 2006/7/EC); however, in the 2006 revision of this Directive (rBWD, CEU, 2006), the enterovirus parameter was withdrawn. Only the bacterial parameters, intestinal enterococci and E. coli have been since considered (Directive 2006/7/EC (rBWD, CEU, 2006; Mansilha et al., 2009)).

It should be noted, however, that analysis for just certain bacteria and/or parasites, most commonly used to assess water quality, does not always provide a sufficient indication of fecal pollution (Sinclair et al., 2009; Okoh et al., 2010). Several studies have shown that levels of indicator bacteria do not necessarily correlate with those of viruses, particularly when fecal indicator concentrations are low (Wyn-Jones et al., 2010). For example, adenovirus was reported in a swimming pool in Greece as the source of an adenovirus outbreak, while all bacteriological indicators tested were negative (Papapetropoulou and Vantarakis, 1998). This particular outbreak coincided with the loss of chlorine residual in the pool, thereby emphasizing the need to assure chlorinated pool waters to protect against not only possible bacterial agents of disease, but also viral agents.

More recently, a recommendation to review the current bathing water directive 2006/7/CE has been issued as the result of a research project (EU Framework 6 Project VIROBATHE, Project number 513648), in order to add adenovirus and norovirus molecular detection to the current European Directive (Wyn-Jones et al., 2010). The reason for this recommendation is that viral and current bacterial indicators do not correlate and so current bacterial indicator limits do not exclude viral contamination in pathogenic levels. Recent data suggests that the 
adding of another bacterial indicator correlates with adenoviruses (Sauer et al., 2011) but not always (McQuaig et al., 2012).

As a conclusion of the meeting and in accordance with Sinclair et al. (2009), growing recognition of the importance of viruses as etiological agents of the gastrointestinal infections suggests they, too, should be useful indicators of human fecal pollution, in addition to bacterial and parasitic parameters.

\section{Sampling, detection and identification}

\subsection{Sample collection}

From the discussion on the standardization of sampling methods for sand, three possibilities were taken into account: analyzing only the wet sand, only the dry sand, or both. Analyzing wet sand instead of only dry sand is recommended by the workshop participants since many of the microorganisms detailed above, including parasites and viruses, are extremely moisture-content dependent for survival. Therefore, and for an experimental period of time, samples should be collected from both wet and dry sands.

Accurate monitoring for levels of enterococci in sand is somewhat difficult. According to some monitoring studies conducted by the World Health Organization (WHO, 2003) "sand contamination is highly variable over short distances, making interpretation of results difficult", a finding supported by Bonilla et al. (2007), who found high variation over a few centimeters. One solution for the high heterogeneity is to collect samples from many different locations and analyze a composite of these samples as recommended by Phillips et al. (2011). It is recognized however that if spatial resolution is important, then collecting individual samples would be necessary.

The methodology used to collect composite samples from both wet and dry sand is identical. Sample collection for wet sands was defined as that area up to 1 or $2 \mathrm{~m}$ from the sea during low tide. These samples will not necessarily reproduce the results of water samples. They may in some cases reflect runoff or degradation of organic material and influences of beach users.

The consensus reached by the meeting participants was that the sand samples (one set wet and one set of dry sand) are to be collected in three equidistant points along the beach, attempting to represent the beach sand as a whole. It was agreed that this was sufficient taking into account the cost of performing multiple sand analyses for a single beach. The frequency of sampling did not generate any particular recommendation concerning timing but it was agreed that water and sand samples should be collected simultaneously (at the same time) in order to avoid wasting human and financial resources.

\subsection{Detection and identification}

A significant amount of research has been directed at maximizing the procedure used to quantify bacteria in sand, and a variety of techniques have been explored. In an extensive analysis of laboratory methods, Boehm et al. (2009) examined the processing of indicator bacteria from beach sand using a variety of techniques for physical agitation, elutriation, blending, decanting and filtering. They aimed to determine what combination of methods yielded the most consistency and accuracy in results. Ultimately, they determined that the preferred method included 2 min of hand-shaking to agitate bacterial cells from the sand into the elutriate, followed by a short settling period and a single rinse. They concluded that standardization of the method-tested on sands from California, Florida, and Lake Michigan-would allow more accurate comparisons among beach locations worldwide (Boehm et al., 2009).

The current laboratory method used in Portugal to analyze sand for microorganisms is summarized, as follows. Sterilized, distilled water is added to a sand sample (40-50 g), and the mixture is agitated (not vigorously) in order to dislodge and extract microorganisms. $0.2 \mathrm{~mL}$ of the supernatant is then spread onto media in a Petri dish, followed by incubation, growth and identification of individual colonies of fungi. For bacteria, Colilert ${ }^{\circ}$ and Enterolert ${ }^{\circledR}$ (IDEXX Laboratories, Inc., ME, USA) have been used to detect $E$. coli and enterococci, as thoroughly described in Sabino et al. (2011). For the detection of helminth eggs a sedimentation method may be used.

The basic steps in the analysis of environmental recreational water for presence of viruses include sampling, concentration, and specific virus detection. The concentration step is critical, since viruses may be present in low numbers in water (Prata et al., 2012). Concentration of recreational water samples is performed by filtration through nitrocellulose membranes, elution, and organic flocculation (Wyn-Jones and Sellwood, 2001). Ultracentrifugation is also an efficient alternative concentration method (Prata et al., 2012). Another alternative method of filtration is through VIRADEL cartridges filter (Ortega et al., 2009), based on standard protocols (US EPA, 2001).

Conventional microbiological methods for identifying microorganisms are laborious and time-consuming, involving days of culturing and identification by microscopic or biochemical characteristics. For fungi and parasites, there is also the need of a high level of expertise to identify the species detected. Moreover, certain microorganisms that may occur in sand samples are not cultivable on available media (Oliver, 2002) or are not present in high enough numbers to allow detection (Guy et al., 2003). An alternative and newer method is quantitative polymerase chain reaction (qPCR). This method has proven to be faster (a few hours) and more effective tool for detecting and quantifying microorganisms in water, including water from recreational beaches (Haugland et al., 2005, 2012). Moreover, qPCR assays have been developed for detecting specific adeno- and polyomaviruses, bacteria, and protozoa from different water sources. There is, however, a need to standardize qPCR protocols for use as an analytical diagnostic tool for routine monitoring. Nevertheless, the US EPA is currently considering qPCR as a rapid analytical tool to detect and quantify fecal indicator bacteria in recreational waters (Shanks et al., 2012).

For parasites, the recommended methods for detection and identification of Cryptosporidium oocysts and Giardia cysts are described in US EPA (2005 method \#1623). The detection of Toxoplasma oocysts in environmental samples is still under development. One practical method (Schwab and McDevitt, 2003) is based on the detection of DNA of $T$. gondii oocysts isolated from water. This method requires the amplification of the B1 gene by PCR (Hohlfeld et al., 1994). Moreover, Howe et al. (1997) suggest the amplification of both ends of the SAG2 gene by PCR, in order to genotype water-borne T. gondii.

For viruses, nucleic acids are extracted from the concentrate and are used as templates for DNA amplification by PCR. This can be preceded by reverse transcriptase in the case of RNA virus. An internal control must be added to samples prior to PCR to guard against false negative results (Vennema et al., 2002; Wyn-Jones et al., 2010). PCR products are then separated by agarose gel electrophoresis and visualized under UV light. A more sensitive detection of viral nucleic acids can be achieved by coupling PCR with probe detection, using the Real-Time PCR technology (Bosch et al., 2011; Gibson and Schwab, 2011). More recently, a new approach to PCR using magnetic beads has proven useful and more robust in detecting several enteric viruses in environmental water (Wong et al., 2012).

Another approach for virus detection and identification involves the use of traditional cell culture methods; shortcomings include unavailability of cell culture systems for all viruses, lengthy culture time, and lack of in vitro cytopathic effect in all viruses (Papapetropoulou and Vantarakis, 1998; Wyn-Jones and Sellwood, 2001 Bosch et al., 2011). As stated, the viruses most frequently associated with recreational water-borne disease outbreaks are enterovirus (Coxsackie viruses, echoviruses and hepatitis A virus), adenovirus, and enteric virus (noroviruses, astroviruses, adenoviruses 40 and 41). Hence, for the workshop participants, these groups are most important for analysis in recreational waters and within wet sand samples. 
This meeting (Microareias 2012) resulted in the conclusion of the following: culture methods will be maintained and routinely used as a screening method for cultivable microorganisms, whereas molecular methodologies (already in use or to be implemented) will be applied to the detection of non-cultivable microorganisms or in order to more rapidly detect possible outbreaks. It is understood that routine monitoring using molecular technologies would require a considerable investment in training the workforce and in upgrading supplies and equipment. However, the benefits of such monitoring could potentially outweigh the costs through improved beach quality and beachgoer health.

\section{Recommendations for addressing human health risk}

Restricting beach monitoring to beach water and excluding sand creates a gap in assessing the overall health risks in beach areas, including indirect risks from the washoff from sand and direct effects from contact with the sand. It may be worthwhile to determine if monitoring microbial contamination of beach sands, using fecal indicators or other variables such as environmental factors (e.g. organic littering, wash-off of algae, frequent presence of wildlife shows a relationship with water quality in the surrounding vicinity. If a relationship exists, water monitoring results could become an indicator of sand quality. Initial surveys of beach sand directly could provide a better understanding of potential health risks in a given area (Shibata and Solo-Gabriele, 2012).

A wide variety of pathogens should be included for screening in different sand zones. This would help to establish any links between illnesses and the range of pathogens detected. These might include C. perfringens (sporulating longer-term fecal indicator) and other microorganisms, such as P. aeruginosa, S. aureus, Candida albicans and dermatophytes, responsible for skin and mucous membrane infections (Shah et al., 2011; Pinto et al., 2012; WHO, 2003). In recent studies, a positive correlation was established between indicator microorganisms and some pathogens, namely helminthes, yeast (Candida) and methicillin-resistant strains of S. aureus (MRSA) (Shah et al., 2011). Some of the 'new' microbial agents (e.g., Exophiala sp.) may be of interest too. In addition to the use of newer pathogens or indicators, the use of molecular technology (e.g., PCR) could also improve our understanding of health risk associated with sand. These decisions will need to be based on infectivity of potential agents, the difficulty in their isolation in culture medium in the laboratory, and the urgency needed for results, so as to identify sources of an outbreak to inform health authorities to restrict public access to these areas.

In a prior study, to determine the presence of yeasts, pathogenic fungi, dermatophytes, total coliforms, E. coli and intestinal enterococci in sand, a sub-group of the workshop participants analyzed samples from thirty-three beaches across Portugal over a five-year period (2006-2010). We reported the results of this study as to the microbiological quality of the sand at selected beaches, including the distribution of bacteria and fungi collected from beach sands. Based on variations in the concentrations of these microorganisms from beach to beach we proposed certain threshold values for selected microbiological indicators. The results of this study provided a useful baseline for assessment of sand beach microbiological flora, and served as a reminder of the occurrence of potentially harmful fungi and bacteria in these environments (Pereira et al., 2013; Sabino et al., 2011). The conclusions of this study are that beach cleaning improves the recreational qualities of the beach in terms of organic content in the sand, but that the impact of water quality is less evident. The ecological effects seem to be small even though the abundance of several animal species was less at cleaned beaches, probably because of reduced food resources.

Rare incidence of pathogen isolation in sand does not necessarily equate to a lower risk for bathers. Differences in actual presence of pathogens and the level of their detection may differ significantly because of technical limitations to measure all pathogens accurately. Pathogens may reside on the sand surface, in crevices, or in biofilms that adhere to sand, which complicates pathogen quantification (Wang et al., 2010). Environmental factors and sanitary conditions of sandy shores (e.g. hydrometeorological and physical/chemical parameters as well as solar insolation and tidal period) may also impact microbial levels in sand and water (Abdelzaher et al., 2010; Shah et al., 2011; Phillips et al., 2011; Brandão et al., 2002). In addition to public health concerns to beachgoers, one must also consider occupational hazards for workers at sand beaches, such as life guards and staff from surrounding restaurants etc. Their exposure time to fungal and bacteria species present in sand is increased due to their professional activities (Viegas et al., 2010).

\section{Additional meeting highlights}

Other points were raised during the meeting that related to public health risk. These included the need to address infestations of insects, including mosquitoes, in areas that promote their proliferation, and also the importation of sands that may harbor parasites and harmful arthropods. For example, we discussed the possible presence of eggs of poisonous arachnids, resulting from the replacement of sand or construction of artificial beaches with sand imported from tropical regions. Also mentioned was the relevance of analyzing sandbox sand from public playgrounds, the same way and for the same reasons as those described for beach sands. This may be particularly relevant to the detection of toxoplasma associated with cats which frequently "visit" such sandboxes.

Generally speaking, the behavior of beachgoers and bathers can directly affect the microbiological quality of sand. As a result, implementing simple steps such as having enough garbage containers available on beaches or limiting the presence of pets on crowded beaches can be important in reducing human exposure to various pathogens. Sanitary management of beaches can play an important role with regard to public health. It is worth noting that WHO (2003) does not recommend the disinfection of sand but recommends the proper management of the coast instead (Pinto et al., 2012). Our belief is that potential public health issues concerning both sand and water quality of beaches should be taken into account in future policy decisions. In the event that beach sand is to be remediated, the use of chlorine (Mika et al., 2009) and iodine (Sabino et al., 2011) may be warranted.

Finally, it should be stressed that the microbiological monitoring of beach-sand quality needs to be performed. This type of testing should be initiated despite the absence of quantitative criteria or known threshold levels; at a minimum, it would allow the gathering of data for developing and improving future studies to set standard protocols and establish criteria to assess risks to public health. Such studies would also be useful for implementing preventive measures or verifying effectiveness for beach sanitation programs or educational campaigns for beachgoers and local traders. The authors propose to define the indicators for sand health quality and implement a monitoring and national management program on designated beaches, to be completed by 2015 .

\section{Acknowledgments}

The authors wish to thank the remainder participants of Microareias 2012, who generated the fruitful discussions that are the basis of this paper. We thank Dr. Bruce Campbell, USDA-retired, for his collaboration in reviewing this Manuscript. This article is Contribution 1806 of the USGS Great Lakes Science Center.

\section{References}

Abdallah SA, Elmanama AA, Fahd MIS, Afifi S. Microbiological beach sand quality in the Gaza Strip in comparison to seawater. Pol J Environ Stud 2005;14(6):841-50. 
Abdelzaher AM, Wright ME, Ortega C, Solo-Gabriele HM, Miller G, Elmir S, et al. Presence of pathogens and indicator microbes at a non-point source subtropical recreational marine beach. Appl Environ Microbiol 2010;76(3):724-32.

Alm EW, Burke J, Spain A. Fecal indicator bacteria are abundant in wet sand at freshwater beaches. Water Res 2003;37:3978-82.

Anderson IH. In vitro survival of human pathogenic fungi in Hawaiian beach sand. Sabouradia 1979;17:13-22.

Ângelo $\mathrm{H}$. Dispositions légales et stratégies préventives de la toxoplasmose congénitale au Portugal. Arch Pediatr 2003;10:25-6.

Ashbee HR, Evans EG, Viviani MA, Dupont B, Chryssanthou E, Surmont I, et al. ECMM working group on histoplasmosis - histoplasmosis in Europe: report on an epidemiological survey from the European Confederation of Medical Mycology working group. Med Mycol 2008;46(1):57-65. [Feb].

Aubert D, Villena I. Detection of Toxoplasma gondii oocysts in water: proposition of a strategy and evaluation in Champagne-Ardenne Region, France; 2009.

Badgley BD, Nayak BS, Harwood VJ. The importance of sediment and submerged aquatic vegetation as potential habitats for persistent strains of enterococci in a subtropical watershed. Water Res 2010;44(20):5857-66. http://dx.doi.org/10.1016/j.watres.2010.07.005.

Benenson MW, Takafuji ET, Lemon SM, Greenup RL, Sulzer AJ. Oocyst-transmitted toxoplasmosis associated with ingestion of contaminated water. $\mathrm{N}$ Engl J Med 1982;307(11):666-9.

Beversdorf L, Borstein-Forst S, McLellan S. The potential for beach sand to serve as a reservoir for Escherichia coli and the physical influences on cell die-off. J Appl Microbiol 2007; 102:1372-81.

Boehm AB, Weisberg SB. Tidal forcing of enterococci at marine recreational beaches at fortnightly and semidiurnal frequencies. Environ Sci Tech 2005;39:5575-83.

Boehm AB, Griffith J, McGee CD, Edge T, Solo-Gabriele HM, Whitman RL, et al. Faecal indicator bacteria enumeration in beach sand: a comparison study of extraction methods in medium to coarse sands. J Appl Microbiol 2009;107:1740-50.

Bonilla TD, Nowosiellski K, Cuvelier M, Hartz A, Grenn M, Esiobu N, et al. Prevalence and distribution of fecal indicator organisms in South Florida beach sand and preliminary assessment of health effects associated with beach sand exposure. Mar Pollut Bull 2007:54(9):1472-82

Bosch A, Bosch A, Sanchez G, Abbaszadegan M, Carducci A, Guix S, et al. Analytical methods for virus detection in water and food. Food Anal Methods 2011;4: 4-12.

Bowie WR, King AS, Werker DH, Isaac-Renton JL, Bell A, Eng SB, et al. Outbreak of toxoplasmosis associated with municipal drinking water. The BC Toxoplasma investigation team. Lancet 1997;350(9072):173-7.

Brandão J, Wergikosky B, Rosado C, Noronha G, Veríssimo C, Falcão ML, et al. Qualidade Microbiológica de Areias de Praias Litorais: relatório final. Instituto do Ambiente; 2002.

Burton G, Gunnison D, Lanza G. Survival of pathogenic bacteria in various freshwater sediments. Appl Environ Microbiol 1987;53:633-8.

Byappanahalli MN, Fowler M, Shively D, Whitman RL. Ubiquity and persistence of Escherichia coli in a Midwestern coastal stream. Appl Environ Microbiol 2003;69: 4549-55.

Carillo-Muñoz AJ, Torres-Rodriguez JM, Madrenys-Brunet N, Dronda-Ayza A. Comparative study on the survival of 5 species of dermatophytes and Scopulariopsis brevicaulis in beach sand under laboratory conditions. Rev Iberoam Micol 1990;7:36-8.

CEU. Directive 2006/7/EC of the European Parliament and of the Council of 15 February 2006 concerning the management of bathing water quality and repealing Directive 76/160/EEC; 2006

Chanqueo L, Gutiérrez C, Tapia C, Silva V, Razeto L, Misad C. Infeccion rinosinusal por Scedosporium apiospermum en un hospedero imunocompetente. Rev Chilena Infectol 2009;26(5):453-6.

Chen J, Zhou DH, Nisbet AJ, Xu MJ, Huang SY, Li MW, et al. Advances in molecular identification, taxonomy, genetic variation and diagnosis of Toxocara spp. Infect Genet Evol 2012;12:1344-8.

Chowdhary A, Randhawa HS, Boekhout T, Hagen F, Klaassen CH, Meis JF. Temperate climate niche for Cryptococcus gattii in northern Europe. Emerg Infect Dis 2012;18(1): 172-4. [January].

Colford Jr JM, Wade TJ, Schiff KC, Wright CC, Griffith JF, Sandhu SK, et al. Water quality indicators and the risk of illness at beaches with nonpoint sources of fecal contamination. Epidemiology 2007;18:27-35.

Conseil Supérieur d'Hygiène Publique de France. Qualité microbiologique des sables: essai d'un nouveau précédé de désinfection (Microbiological quality of sea sand: a trial of a new disinfection protocol). ; 1990 [Paris].

Cortez K, Roilides E, Quiroz-Telles F, Meletiadis J, Antachopoulos C, Knudsen T, et al. Infections caused by Scedosporium spp. Clin Microbiol Rev 2008;1(21):157-97.

Cotte L, Rabodonirina M. Chapuis F, Bailly F, Bissuel F, Raynal C, et al. Waterborne outbreak of intestinal microsporidiosis in persons with and without human immunodeficiency virus infection. J Infect Dis 1999;180(6):2003-8.

Desmarais TR, Solo-Gabriele HM, Palmer CJ. Influence of soil on fecal indicator organisms in a tidally influenced subtropical environment. Appl Environ Microbiol 2002;68: $1165-72$.

Directive 2006/7/EC of the European Parliament and of the Council of 15 February 2006 concerning the management of bathing water quality and repealing Directive 76/160/EEC as amended by Regulation 596/2009/EC.

Dorfman M, Rosselot KS. Testing the waters: a guide to water quality at vacation beaches. Twentieth annual report. Natural Resources Defense Council; 2010.

Doyle J, Tunnicliff B, Kramer R, Kuehl R, Brickler S. Instability of fecal coliform populations in waters and bottom sediments at recreational beaches in Arizona. Water Res 1992;26:979-88.

Dubey JP. Advances in the life cycle of Toxoplasma gondii. Int J Parasitol 1998;28(7): 1019-24.
Dumètre A, Le Bras C, Baffet M, Meneceur P, Dubey JP, Derouin F, et al. Effects of ozone and ultraviolet radiation treatments on the infectivity of Toxoplasma gondii oocysts. Vet Parasitol 2008;153(3-4):209-13.

Dunsmore JD, Thompson RC, Bates IA. Prevalence and survival of Toxocara canis eggs in the urban environment of Perth, Australia. Vet Parasitol 1984;16(3-4):303-11.

Elmore SA, Jones JL, Conrad PA, Patton S, Lindsay DS, Dubey JP. Toxoplasma gondii: epidemiology, feline clinical aspects, and prevention. Trends Parasitol 2010;26(4):190-6.

Esiobu N, Mohammed R, Echeverry A, Green M, Bonilla T, Hartz A, et al. The application of peptide nucleic acid probes for rapid detection and enumeration of eubacteria, Staphylococcus aureus and Pseudomonas aeruginosa in recreational beaches of S Florida. J Microbiol Methods 2004;57:157-62

Fanning S, Mitchell AP. Fungal biofilms. PLoS Pathog 2012;8(4):e1002585. [Published online April 5].

Ferguson DM, Moore DF, Getrich MA, Zhowandai MH. Enumeration and speciation of enterococci found in marine and intertidal sediments and coastal water in southern California. J Appl Microbiol 2005;99:598-608.

Field KG, Samadpour M. Fecal source tracking, the indicator paradigm, and managing water quality. Water Res 2007;41:3517-38.

Fleisher JM, Fleming LE, Solo-Gabriele HM, Kish JK, Sinigalliano CD, Plano L, et al. The BEACHES Study: health effects and exposures from non-point source microbial contaminants in subtropical recreational marine waters. Int J Epidemiol 2010;39:1291-8

Ganavalli AS, Kulkarni RD. Cladophialophora bantiana the neurothopic fungus. J Clin Diagn Res 2001;5(6):1301-6. [Sup 1].

Ge Z, Nevers MB, Schwab DJ, Whitman RL. Coastal loading and transport of Escherichia coli at an embayed beach in Lake Michigan. Environ Sci Technol 2010;44:6731-7.

Ghinsberg RC, Dov LB, Rogol M, Sheinberg Y, Nitzan Y. Monitoring of selected bacteria and fungi in sand and sea water along the Tel Aviv coast. Microbios 1994;77(310):29-40.

Ghinsberg R, Drasinover V, Sheinber Y, Nitzan Y. Seasonal distribution of Aeromonas hydrophila and Vibrio species in Mediterranean coastal water and beaches: a possible health hazard. Biomed Lett 1995;51:151-9.

Gibson KE, Schwab KJ. Tangential-flow ultrafiltration with integrated inhibition detection for recovery of surrogates and human pathogens from large-volume source water and finished drinking water. Appl Environ Microbiol 2011;77(1):385-91.

Groseclose SL, Braithwaite WL, Hall PA, Knowles C, Adams DA, Connor F, et al. Summary of notifiable diseases - United States 2000. MMWR 2002;49(53):1-102.

Guy RA, Payment P, Krull UJ, Horgen PA. Real-time PCR for quantification of Giardia and Cryptosporidium in environmental water samples and sewage. Appl Environ Microbiol 2003;69(9):5178-85

Haile RW, Witte JS, Gold M, Cressey R, McGee C, Millikan RC, et al. The health effect of swimming in ocean water contaminated by storm drain runoff. Epidemiology 1999;10:355-63.

Halliday E, Gast RJ. Bacteria in beach sands: an emerging challenge in protecting coastal water quality and bather health. Environ Sci Tech 2011:45:370-9.

Hartz A, Cuvelier M, Nowosielski K, Bonilla T, Green M, Esiobu N, et al. Survival potential of Escherichia coli and enterococci in subtropical beach sand: implications for water quality managers. J Environ Qual 2008;37:898-905.

Haugland RA, Siefring SC, Wymer LJ, Brenner KP, Dufour AP. Comparison of Enterococcus measurements in freshwater at two recreational beaches by quantitative polymerase chain reaction and membrane filter culture analysis. Water Res 2005;39(4):559-68.

Haugland RA, Siefring S, Lavender J, Varma M. Influences of sample interference and interference controls on quantification of enterococci fecal indicator bacteria in surface water samples by the qPCR method. Water Res 2012;46(18): 5989-6001.

Heany C, Sams E, Wing S, Marshall S, Brenner K, Dufour AP, et al. Contact with beach sand among beachgoers and risk of illness. Am J Epidemiol 2009;170(2):167-72.

Heaney CD, Sams E, Dufour AP, Brenner KP, Haugland RA, Chern E, et al. Fecal indicators in sand, sand contact, and risk of enteric illness among beachgoers. Epidemiology 2012;23:95-106.

Hohlfeld P, Daffos F, Costa JM, Thulliez P, Forestier F, Vidaud M. Prenatal diagnosis of congenital toxoplasmosis with a polymerase-chain- reaction test on amniotic fluid. $\mathrm{N}$ Engl J Med 1994;331:695-9.

Howe DK, Honoré S, Derouin F, Sibley LD. Determination of genotypes of Toxoplasma gondii strains isolated from patients with toxoplasmosis. J Clin Microbiol 1997;35: 1411-4.

Irvine K, Pettibone G. Dynamics of indicator bacteria populations in sediment and rive water near combined sewer outfall. Environ Technol 1993;14:531-42.

Júlio C, Vilares A, Oleastro M, Ferreira I, Gomes S, Monteiro L, et al. Prevalence and risk factors for Giardia duodenalis infection among children: a case study in Portugal. Parasites Vectors 2012a;5:22

Júlio C, Sá C, Ferreira I, Martins S, Oleastro M, Ângelo H, et al. Waterborne transmission of Giardia and Cryptosporidium at river beaches in Southern Europe (Portugal). J Water Health 2012b;10(3):484-96.

Knutsen AP, Slavin RG. Allergic bronchopulmonary aspergillosis in asthma and cystic fibrosis. Clin Dev Immunol 2011. http://dx.doi.org/10.1155/2011/843763.

Korich DG, Mead JR, Madore MS, Sinclair NA, Sterling CR. Effects of ozone, chlorine dioxide, chlorine, and monochloramine on Cryptosporidium parvum oocyst viability. App Environ Microbiol 1990;56(5):1423-8.

Lane S, Lloyd D. Current trends in research into the waterborne parasite Giardia. Crit Rev Microbiol 2002;28(2):123-47.

Layton BA, Cao Y, Ebentier DL, Hanley K, Ballesté E, Brandão J, et al. Performance of human fecal anaerobe-associated PCR-based assays in a multi-laboratory method evaluation study. Water Res 2013;47:6897-908. [Jul 5].

Lopes AP, Dubey JP, Moutinho O, Gargaté MJ, Vilares A, Rodrigues M, et al. Seroepidemiology of Toxoplasma gondii infection in women from the North of Portugal in their childbearing years. Epidemiol Infect 2012;140(5):872-7. 
Mac Kenzie WR, Hoxie NJ, Proctor ME, Gradus MS, Blair KA, Peterson DE, et al. A massive outbreak in Milwaukee of Cryptosporidium infection transmitted through the public water supply. N Engl J Med 1994;331(3):161-7. [Erratum in: N Engl J Med 1994, 331(15):1035].

Mansilha CR, Coelho CA, Heitor AM, Amado J, Martins JP, Gameiro P. Bathing waters: new directive, new standards, new quality approach. Mar Pollut Bull 2009:58:1562-5.

Matos O, Tomás A, Aguiar P, Casemore D, Antunes F. Prevalence of cryptosporidiosis in AIDS patients with diarrhoea in Santa Maria Hospital, Lisbon. Folia Parasitol (Praha) 1998:45(2):163-6.

Maunula L, Kalso S, von Bonsdorff C-H, Pönkä A. Wading pool water contaminated with both noroviruses and astroviruses as the source of a gastroenteritis outbreak Epidemiol Infect 2004;132(4). [737e743].

McQuaig S, Griffith J, Harwood VJ. Association of fecal indicator bacteria with human viruses and microbial source tracking markers at coastal beaches impacted by nonpoint source pollution. Appl Environ Microbiol 2012;78(18):6423-32. [September].

Mika KB, Imamura G, Chang C, Conway V, Fernandez G, Griffith JF, et al. Pilot- and bench-scale testing of faecal indicator bacteria survival in marine beach sand near point sources. J Appl Microbiol 2009;107:72-84

Morrissey CO. Advancing the field: evidence for new management strategies in invasive fungal infections. Curr Fungal Infect Rep 2013;7(1):51-8.

Nucci M, Anaissie E. Fusarium infections in immunocompromised patients. Clin Microbiol Rev 2007;20:695-704

Obiri-Danso K, Jones K. Intertidal sediment as reservoirs of hippurate negative campylobacters, salmonellae, and fecal indicators in three EU recognized bathing waters in north-west England. Water Res 2000;34:519-27.

Okoh AI, Sibanda T, Gusha SS. Inadequately treated wastewater as a source of human enteric viruses in the environment. Int J Environ Res Public Health 2010;7:2620-37.

Oliver JD. The viable but non culturable state in bacteria. J Microbiol 2002;43(5):93-100

Ortega C, Solo-Gabriele HM, Abdelzaher A, Wright M, Deng Y, Stark LM. Correlation between microbial indicators, pathogens, and environmental factors in subtropical estuary. Mar Pollut Bull 2009;58:1374-81.

Oshiro R, Fujioka RS. Sand, soil and pigeon droppings-sources of indicator bacteria in the water of Hanauma Bay, Oahu, Hawaii. Water Sci Technol 1995;31:251-4.

Papadakis JA, Mavrido A, Richardson SC, Lambiri M, Marcelou U. Bather related microbial and yeast populations in sand and seawater. Water Res 1997;31:799-804.

Papapetropoulou M, Vantarakis AC. Detection of adenovirus outbreak at a municipal swimming pool by nested PCR amplification. J Infect 1998;36:101-3.

Pereira E, Figueira C, Aguiar N, Vasconcelos R, Vasconcelos S, Calado G, et al. Microbiological and mycological beach sand quality in a volcanic environment: Madeira archipelago, Portugal. Sci Total Environ 2013;461-462C:469-79. [Jun 6].

Phillips MC, Solo-Gabriele HM, Reniers AJHM, Wang JD, Kiger RT, Abdel-Mottaleb N. Pore water transport of enterococci out of beach sediments. Mar Pollut Bull 2011a;62: 2293-8.

Phillips M, Solo-Gabriele HM, Piggot AM, Klaus JS, Zhang Y. Relationships between sand and water quality at recreational beaches. Water Res 2011b;45(20):6763-9.

Pinto KC, Hachich EM, Sato MIZ, Di Bari M, Coelho MCLS, Matté MH, et al. Microbiological quality assessment of sand and water from three selected beaches of South Coast, São Paulo State, Brazil. Water Sci Technol 2012;2475-2482.

Prata C, Ribeiro A, Cunha A, Gomes NCM, Almeida A. Ultracentrifugation as a direct method to concentrate viruses in environmental waters: virus-like particle enumeration as a new approach to determine the efficiency of recovery. J Environ Monit 2012;14:64-70.

Sabino R, Veríssimo C, Cunha MA, Wergikoski B, Ferreira FC, Rodrigues R, et al. Pathogenic fungi: an unacknowledged risk at coastal resorts? New insights on microbiological sand quality in Portugal. Mar Pollut Bull 2011;62(7):1506-11.

Sanchez PS, Agudo EG, Castro FG, Alves MN, Martins MT. Evaluation of the sanitary quality of marine recreational waters and sands from beaches of the São Paulo State, Brazil. Water Sci Technol 1986;18(10):61-72.

Sato MIZ, Di Bari M, Lamparelli CC, Truzzi AC, Coelho MCLS, Hachich EM. Sanitary quality of sands from marine recreational beaches of São Paulo, Brazil; 2005.

Sauer EP, Vandewalle JL, Bootsma MJ, McLellan SL. Association of fecal indicator bacteria with human viruses and microbial source tracking markers at coastal beaches impacted by nonpoint source pollution. Water Res 2011;45(14):4081-91.

Schwab KJ, McDevitt JJ. Development of a PCR-Enzyme Immunoassay Oligoprobe Detection Method for Toxoplasma gondii Oocysts, Incorporating PCR Controls. Appl Environ Microbiol 2003;69:5819-25.

Shah A, Abdelzaher AM, Phillips M, Hernandez R, Solo-Gabriele HM, Kish J, et al. J App Microbiol 2011(110):1571-83

Shanks OC, Sivaganesan M, Peed L, Kelty CA, Blackwood AD, Greene MR, et al. Interlaboratory comparison of real-time PCR protocols for quantification of general fecal indicator bacteria. Environ Sci Technol 2012;46(2):945-53.

Shapiro K, Conrad PA, Mazet JA, Wallender WW, Miller WA, Largier JL. Effect of estuarine wetland degradation on transport of Toxoplasma gondii surrogates from land to sea. Appl Environ Microbiol 2010;76(20):6821-8.

Shibata T, Solo-Gabriele HM. Quantitative microbial risk assessment of human illnes from exposure to marine beach sand. Environ Sci Technol 2012;46:2799-805.

Shibata T, Solo-Gabriele HM, Fleming L, Elmir S. Monitoring marine recreational water quality using multiple microbial indicators in an urban tropical environment. Water Res 2004;38:3119-31.

Sinclair RG, Jones EL, Gerba CP. Viruses in recreational water-borne disease outbreaks: review. J Appl Microbiol 2009;107(6):1769-80.
Sinigalliano CD, Fleisher J, Gidley ML, Solo-Gabriele HM, Shibata T, Plano LRW, et al. Traditional and molecular analyses for fecal indicator bacteria in non-point source subtropical recreational marine waters. Water Res 2010;44:3763-72.

Slifko TR, Smith HV, Rose JB. Emerging parasite zoonoses associated with water and food. Int J Parasitol 2000;30(12-13):1379-93. [Nov].

Smith HV, Cacciò SM, Cook N, Nichols RA, Tait A. Cryptosporidium and Giardia as foodborne zoonoses. Vet Parasitol 2007;149(1-2):29-40.

Stewart JR, Gast RJ, Fujioka RS, Solo-Gabriele HM, Meschke JS, Amaral-Zettler LA, et al. The coastal environment and human health: Microbial indicators, pathogens, sentinels and reservoirs. Environ Health 2008;7(S3). http://dx.doi.org/10.1186/1476-069X7-S2-S3.

Stone DL, Harding AK, Hope BK, Slaughter-Mason S. Exposure assessment and risk of gastrointestinal illness among surfers. J Toxicol Environ Health A 2008;71: $1603-15$.

Sunderland D, Graczyk TK, Tamang L, Breysse PN. Impact of bathers on levels of Cryptosporidium parvum oocysts and Giardia lamblia cysts in recreational beach waters. Water Res 2007;41:3483-9.

Thompson RCA, Hopkins RM, Homan WL. Nomenclature and genetic groupings of Giardia infecting mammals early taxonomy. Parasitology 2000;16(5):210-3.

U.S. Environmental Protection Agency. Implementation guidance for ambient water quality criteria for bacteria-1986. Washington, DC: U.S. EPA Office of Water; 2000 [EPA-823-D-00-001].

US EPA. Method 1602: Male-specific $(\mathrm{F}+)$ and somatic coliphage in water by single agar (SAL) procedure. EPA 821-R-01-029. Washington, DC: US EPA, Office of Water; 2001.

U.S. Environmental Protection Agency. Recreational water quality criteria. U.S. EPA Office of Water, Document 820-F-12-058, Washington, D.C.; 2012

United Nations World Tourism Organization (UNWTO). Historical perspective of world tourism. Available at:http://www.unwto.org/facts/eng/historical.htm, 2010.

Vantarakis AC, Tsibouxi A, Venieri G, Komninou G, Athanassiadou A, Papapetropoulou M. Evaluation of microbiological quality of coastal waters in Greece. J Water Health 2005;3(4):371-80.

Vasl R, Fattal B, Katzenelson E, Shuval H. Survival of enteroviruses and bacterial indicator organisms in the sea. In: Goddard M, Butler M, editors. Viruses and wastewater treatment. Pergamon Press; 1981. p. 113-6.

Vennema H, de Bruin E, Koopmans EM. Rational optimization of generic primers used for Norwalk-like virus detection by reverse transcriptase polymerase chain reaction. J Clin Virol 2002;25:233-5.

Viegas C, Pinheiro C, Carolino E, Rosado L, Silva Santos C. Risk assessment methodology for surface fungal infection in gymnasium workers in Lisbon: a proposal in Risk Analysis VII Simulation and Hazard Mitigation978-1-84564-472-7; 2010.

Vogel C, Rogerson A, Schatz S, Laubach H, Tallman A, Fell J. Prevalence of yeast in beach sand at three bathing beaches in South Florida. Water Res 2007;41(9):1915-20.

Waap H, Cardoso R, Leitão A, Nunes T, Vilares A, Gargaté MJ, et al. In vitro isolation and seroprevalence of Toxoplasma gondii in stray cats and pigeons in Lisbon, Portugal. Vet Parasitol 2012;187(3-4):542-7. [Jul 6].

Wade TJ, Pai N, Eisenberg JNS, Colford Jr JM. Do US Environmental Protection Agency water quality guidelines for recreational waters prevent gastrointestinal illness? A systematic review and meta-analysis. Environ Health Perspect 2003;111: 1102-9.

Wade TJ, Calderon RL, Brenner KP, Sams E, Beach M, Haugland R, et al. High sensitivity of children to swimming-associated gastrointestinal illness: Results using a rapid assay of recreational water quality. Epidemiology 2008;19:375-83.

Wang J, Solo-Gabriele HM, Abdelzaher A, Fleming L. Estimation of enterococci input from bathers and animals on a recreational beach using camera images. Mar Pollut Bull 2010;60:1270-8

Whitman R, Nevers M. Foreshore sand as a source of E. coli in nearshore water of a Lake Michigan beach. Appl Environ Microbiol 2003;69:5555-62.

Whitman RL, Przybyla-Kelly K, Shively DA, Nevers MB, Byappanahalli MN. Hand-mouth transfer and potential for exposure to E. coli and $\mathrm{F}+$ coliphage in beach sand, Chicago, Illinois. J Water Health 2009; 7:623-9.

WHO - World Health Organization. Guidelines for safe recreational water environments: coastal and freshwater, 1; 2003 [Geneva, Switzerland].

Wong K, Fong T-T, Bibby K, Molina M. Application of enteric viruses for fecal pollution source tracking in environmental waters. Environ Int 2012;45:151-64.

Wright ME, Solo-Gabriele HM, Elmir S, Fleming LE. Microbial load from animal feces at a recreational beach. Mar Pollut Bull 2009;58(11):1649-56.

Wright ME, Solo-Gabriele HM, Abdelzaher AM, Elmir S, Fleming LE. The inter-tidal zone is the geographic location of elevated concentrations of enterococci. Water Sci Technol 2011;63(3):542-9.

Wyn-Jones AP, Sellwood J. A review - enteric viruses in the aquatic environment. J Appl Microbiol 2001;91:945-62.

Wyn-Jones AP, Carducci A, Cook N, D'Agostino M, Divizia M, Fleischer J, et al. Surveillance of adenoviruses and noroviruses in European recreational waters. Water Res 2010;45(3):1025-38

Yamahara KM, Layton BA, Santoro AE, Boehm AB. Beach sands along the California coast are diffuse sources of fecal bacteria to coastal waters. Environ Sci Tech 2007;41: 5415-21.

Yilmaz SM, Hopkins SH. Effects of different conditions on duration of infectivity of Toxoplasma gondii oocysts. J Parasitol 1972;58(5):938-9. 